\title{
MENCIPAKAN SISTEM POLITIK BERDASARKAN PANCASILA SEBAGAI UPAYA PENINGKATAN KETAHANAN NASIONAL
}

\author{
Usman Arief*
}

\begin{abstract}
Abstrak
Setiap bangsa yang merdeka dan berdaulat tentu mempunyai kepentingan utama, yaitu terjaminnya kelangsungan hidup bangsa yang dijiwai oleh niai-nilai ideologi yang dianutnya. Dalam upaya tersebut, setiap bangsa tentu menghadapi AGHT (ancaman, gangguan, hambatan dan tantangan). Demikian pula bangsa Idonesia, dalam upaya mempertahankan kelangsungan hidup berdasarkan nilainilai ideologi Pancasila, senantiasa menghadapi AGHT, baik yang datang dari dalam maupun luar negeri, secara langsung maupun tidak langsung. Untuk keperluan tersebut perlu diciptakan kondisi ketahanan nasional yang kuat. Kondisi ketahanan nasional yang kuat akan terwujud apabila didukung kondisi politik yang kuat. Agar tercipta kondisi Ketahanan Nasional Indonesia di bidang politik yang kuat, maka perlu dibangun suatu sistem politik yang kondusif bagi terwujudnya kondisi politik yang kuat berdasarkan Pancasila. Ada strategi atau cara untuk mencapai tujuan di atas, yaitu berupa tindakan-taindakan yang perlu dilakukan, meliputi : (1) Internalisasi nilai-nilai Ideologi Pancasila, melalui berbagai jalur; (2) Pembangunan dan pemberdayaan kelembagaan, baik supra struktur politik, maupun infra struktur politik; (3) Peningkatan partisipasi politik masyarakat, dengan menyediakan ruang yang lebih lebar bagi masyarakat untuk terlibat dalam kegiatan politik. Apabila ketiga startegi di atas dapat diimplementasikan dengan baik, dalam arti dapat terbentuk sistem politik berdasarkan Pancasila, maka diduga kuat akan dapat meningkatkan kondisi Ketahanan Nasional Indonesia ke level yang lebih tinggi (ulet dan tangguh).
\end{abstract}

Kata Kunci : Sistem Politik, Ideologi Pancasila, Internalisasi, Partisipasi Politik dan Ketahanan Nasional

Setiap bangsa dalam upaya untuk mencapai tujuan nasional, dan menjamin kelangsungan hidup atau eksistensinya, yang merupakan kepentingan utamanya, senantiasa dihadapkan pada ancaman, gangguan, hambatan dan tantangan (AGHT). Atas dasar kenyataan di atas, timbul pertanyaan "Strategi apa yang dianut oleh bangsa Indonesia agar tetap survive dalam menghadapi AGHT tersebut ? "Dengan mempertimbangkan bentuk AGHT serta situasi dan kondisi bangsa kita, maka yang dipilih adalah Strategi Ketahanan Nasional, yang meliputi ketahanan nasional di bidang idelogi, politik, ekonomi, sosial-budaya dan pertahanan keamanan. Ketahanan nasional mempunyai 3 (tiga) wujud, yaitu ketahanan nasioanal sebagai konsepsi, kondisi, maupun sebagai strategi. Ketahanan nasional sebagai strategi

\footnotetext{
* Dosen pada UPM Soshum ITS

jsh Jurnal Sosial Humaniorah, Vol 3 No.2, November 2010 
berpokok pangkal pada masalah upaya mempertahankan kelangsungan hidup bangsa.

Sesuai dengan judul kajian ini, maka akan dikaji hal-hal yang ada kaitannya dengan ketahanan nasional di bidang politik. Ketahanan nasional di bidang politik adalah kondisi dinamik suatu bangsa, berisi keuletan dan ketanguhan yang mengandung kemampuan mengembangkan kekuatan nasional, di dalam menghadapi dan mengatasi segala AGHT dari dalam maupun dari luar, yang langsung atau tidak langsung membahayakan kehidupan politik bangsa dan negara (Winarno. 2005: 175) Agar tercipta kondisi Ketahanan Nasional Indonesia yang kuat, maka perlu diciptakannya sistem politik yang kondusif bagi terciptanya kondisi tersebut, berdasarkan Pancasila.

Ketahanan Nasional Indonesia di bidang politik menghadapi ancaman yang bersumber dari dalam negeri, yaitu berupa kegiatan subversi untuk merongrong idelogi Pancasila dan UUD 1945 serta mengancam persatuan dan kesatuan bangsa, dan kegiatan politik praktis kelompok-kelompok non formal yang secara langsung atau tidak langsung menghalang-halangi upaya perwujudan Pancasila dalam kehidupan bermasyarakat, berbangsa dan bernegara. Dari luar negeri, berupa kegiatan subversi asing yang merugikan kepentingan Indonesia maupun negaranegara ASEAN.

Dengan latar belakang sebagaimana dipaparkan di atas, maka di bawah ini disusun rumusan masalah dalam upaya menciptakan sistem politik yang kondusif bagi terciptanya kondisi Ketahanan Nasional Indonesia yang kuat, yaitu melalui strategi :

1. Bagaimana melakukan internalisasi nilai-nilai ideologi Pancasila guna mewujudkan sistem politik yang diharapkan?.

2. Bagaimana membangun kelembagaan, baik supra struktur politik, maupun infra struktur politik, serta memperdayakan lembaga-lembaga tersebut, agar terwujud sistem politik yang diharapkan?.

3. Bagaimana membuka ruang yang lebih lebar/luas bagi terciptanya partisipasi politik masyarakat, agar terwujud sistem politik yang diharapkan?. 
Selanjutnya, guna menjawab tiga rumusan masalah di atas, maka berikut ini akan dipaparkan 3 (tiga) strategi yang dapat diimplementasikan, yaitu :

\section{Internalisasi Nilai-Nilai Ideologi Pancasila}

Sudah sejak awal kemerdekaan Indonesia, Pancasila diterima sebagai ideologi nasional. Namun dalam praktek kehidupan berbangsa dan bernegara, pengamalan Pancasila sebagai ideologi nasional masih belum terwujud seperti yang diharapkan. Oleh karena itu masih diperlukan upaya berfikir dan bekerja keras untuk mengembangkan Pancasila sebagai ideologi nasional yang mampu menjawab segala tantangan masa depan. Dalam menghadapi dinamika perubahan zaman, terdapat kebutuhan yang mendesak untuk konsisten dengan nilai-nilai dasar kebangsaan yang tercantum dalam Pancasila, serta menerjemahkan nilai-nilai tersebut dalam tahapan yang lebih kongkrit dalam kehidupan politik. Urgensi ini amat dirasakan oleh masyarakat majemuk seperti Indonesia yang senantiasa berada dalam suasana perbenturan berbagai nilai hidup yang berkembang, baik karena interaksi budaya dengan dunia luar, maupun karena kemajemukan nilai di dalam budaya bangsa.

Masyarakat Indonesia adalah masyarakat majemuk. Salah satu kecenderungan yang sangat mungkin terjadi adalah munculnya problem ideologis, yaitu adanya sikap "deterministik" atau sikap mutlak-mutlakan dan mau benar sendiri. Pada gilirannya sikap deterministik akan melahirkan sikap dan perilaku totaliter deterministik dan liberal anarkistik. Adanya sikap dan dan perilaku di atas dapat memunculkan pertanyaan, "Apakah Pancasila itu ideologi tertutup, ataukah terbuka?" Pengkajian mendasar mengenai hakekat Pancasila menunjukkan bahwa Pancasila adalah ideologi terbuka karena Pancasila ada dan tumbuh, serta digali dari struktur maupun kultur masyarkat Indonesia. Jadi Pancasila adalah milik bersama bangsa Indonesia. Pancasila terbuka dalam arti tidak menutup diri terhadap segala hal yang baik dari luar, namun keterbukaan Pancasila ini tidak berarti keterbukaan tanpa acuan, yang anarkistik yang justru akan menjadikan masyarakat Indonesia menjadi bebas, radikal dan lepas dari sifat dasarnya, seperti sikap dan tindakan masyarakat yang mulai menggejala dewasa ini. 
Ada beberapa jalur yang dapat digunakan untuk menginternalisasikan nilainilai ideologi Pancasila, yaitu jalur pendidikan, keluarga, sekolah, lingkungan masyarakat, jalur media masa, jalur organisasi politik, jalur organisasi kemasyarakatan dan sebagainya. Dari pemaparan di atas, dirasa perlu sekali menghidupkan kembali mata kuliah Pancasila di setiap perguruan tinggi, dalam rangka "nation character building" yang selaras dengan nilai-nilai ideologi Pancasila, mengingat posisi startegis mahasiswa sebagai kader pimpinan bangsa di masa depan. Mata kuliah Pancasila yang dimaksud adalah mata kuliah yang berdiri sendiri.

Nilai-nilai Pancasila dapat dikembangkan dalam suasana kebersamaan sehingga menjadi hidup dan operasional dalam semua bidang kehidupan bangsa. Jika perkembangan ideologis dapat berlangsung dalam pengertian ini, maka Pancasila dapat menjadi acuan kebangsaan yang kuat dan berakar. Dewasa ini terlihat gejala bahwa penerimaan pemikiran-pemikiran berdasarkan Pancasila dalam tingkatannya yang umum dan abstrak relative mudah. Namun jika pemikiranpemikiran yang berbobot ideologis sudah sampai kepada hal-hal yang kongkrit, maka masih terlihat adanya perbedaan persepsi yang cukup besar.Adanya perbedaan persepsi yang besar mengenai hal-hal kongkrit, berbobot ideologis, serta menyentuh hal-hal yang asasi tidak bisa dibiarkan berlarut-larut, karena hal ini merupakan indikasi belum kuat dan belum berakarnya nilai-nilai Pancasila dalam masyarakat.

Dalam rangka pelestarian serta pengembangan nilai-nilai Pancasila, baik dalam rangka menjaga konsistensi pembangunan nasional sebagai pembangunan manusia seutuhnya, maupun dalam menghadapi berbagai ancaman , hambatan, tantangan serta gangguan yang timbul dari dalam maupun yang muncul dari luar, diperlukan internalisasi nilai-nilai ideologi Pancasila. Internalisasi nilai-nilai ialah suatu proses penanaman nilai-nilai tertentu secara sadar, agar nilai-nilai tersebut tertanam pada jiwa seseorang atau sekelompok orang. Selanjutnya jiwa yang mempunuyai nilai-nilai tersebut akan merefleksikan nilai-nilai tersebut dalam pola pikir, pola sikap, dan pola tindaknya. Jadi tujuan internalisasi nilai-nilai ideologi Pancasila adalah agar terbentuk manusia Pancasila, setelah terbentuknya manusia Pancasila, pada giliran berikutnya akan terbentuk masyarakat Pancasila. Kedua 
tujuan ini saling berkaitan dan menunjang. Hanya manusia-manusia Pancasila yang dapat membentuk masyarakat Pancasila. Sebaliknya, hanya masyarakat Pancasila yang dapat melahirkan manusia Pancasila.

Di samping itu, perubahan struktural di bidang perekonomian dunia sebagai akibat perkembangan ilmu dan teknologi dan pergeseran strategi global ideologi komunis memerlukan tanggapan dalam kerangka ideologis. Di abad modern yang serba canggih dengan peranan iptek yang sedemikian besarnya, membawa berbagai perubahan nilai maupun struktural. Kenyataan ini mengharuskan kita untuk menjadikan Pancasila sebagai ideologi modern, di mana asas-asas pikir yang bersandarkan penalaran perlu diberikan tempat dalam perkembangan pemikiran ideologis kita. Menghadapi semua itu, pragmatisme tidak cukup karena keputusankeputusan politik tidak bisa diambil dengan sikap bebas nilai. Komitmen terhadap persatuan dan kesatuan bangsa, serta kedaulatan politik, ekonomi dan budaya harus jelas dalam setiap keputusan politik yang diambil. Kepemimpinan politik di masa mendatang, di samping harus memliki komitmen yang kuat pada modernisasi bangsa, harus pula memiliki integritas ideologis yang tinggi. Mengamati perkembangan yang ada, dapat diprediksi bahwa pada tahun 2014, Indonesia mengalami krisis kepemimpinan di berbagai supra struktur politik. Hal ini terihat dari adanya kecendrungan semakin melemahnya komitmen dan integritas para penyelenggara negara dewasa ini.

\section{Pembangunan Dan Pemberdayaan Kelembagaan}

Masalah kelembagaan juga akan merupakan masalah penting karena Pancasila sebagai ideologi yang terbuka dan demokratis adalah juga sekaligus merupakan ideologi nasional sehingga dengan demikian gagasan-gagasan apapun yang mengikat seluruh bangsa haruslah merupakan gagasan nasional Indonesia, baik yang merupakan suptra-stuktural politik yaitu lembaga tertinggi dan tinggi negara, maupun yang merupakan infrastruktur politik, terutama kekuatan sosial politik serta sosial kemasyarakatan. Dalam pengertian ini maka kehidupan yang demokratis, konstistusional dan berdasarkan hokum merupakan bagian yang tak terpisahkan dari kehidupan kelembagan bangsa Indonesia dalam rangka pengamalan 
Pancasila. Dalam hal ini, membangun lembaga-lembaga negara yang sesuai dengan nilai-nilai ideologi Pancasila dan yang mampu menjalankan fungsinya adalah suatu "conditio sine quanon".

Ke depan, diharapkan adanya modernisasi di bidang politik, serta dimungkinkan pula terjadi peningkatan demokrasi politik, sesuai dengan hakekat Pancasila sebagai ideologi terbuka, demokratis, dan dinamis. Dengan demikian yang harus dijadikan titik perhatian adalah pertumbuhan serta perkembangan kelembagaan poltik sehingga mampu mengemban fungsinya secara penuh serta mandiri. Kewenangan serta fungsi kelembagaan politik seperti yang tersurat dalam konstitusi dan dalam peraturan perundang-undangan Indonesia harus benar-benar terwujud, bukan saja dalam pengertiannya yang formal, tetapi juga dalam substansi.

Dalam konteks modernisasi, maka setiap lembaga, apakah itu dalam tingkatan suprastruktur maupun infrastruktur harus menata fungsinya masingmasing sehingga kejelasan fungsi yang dituntut oleh pembaharuan dapat tercipta. Kejelasan fungsional amat diperlukan, sehingga proses pengambilan keputusan serta administrasi dari keputusan mendatang akan terwujud dengan lancar, tertib, berdisiplin serta taat asas terhadap norma, etika, dan mekanisme politik. Namun perlu selalu diingat bahwa kehidupan kelembagaan bukanlah statis, melainkan dinamis. Semua perangkat kelembagan dituntut berperan secara efektif, dalam memecahkan segala permasalahan pembangunan nasional, baik yang merupakan pelaksanaan dari rencana pembangunan nasional maupun masalah lain yang timbul secara tidak terduga sebelumnya. Oleh karena itu sistem kelembagaan harus terus menumbuhkan daya penyesuaian yang tinggi terhadap kenyataan-kenyataan baru, baik yang secara sengaja diciptakan maupun yang muncul dari perkembangan masyarakat itu sendiri. Suatu sistem politik yang secara efektif berinteraksi dengan kenyataan-kenyataan masyarakat akan merupakan jaminan yang kuat bagi terciptanya stabilitas yang dinamis di segala bidang kehidupan.

Tantangan bagi kepemimpinan politik di masa mendatang ialah bahwa masalah kelembagaan akan berkembang sebagai masalah modernisasi politik serta peningkatan demokrasi politik yang memerlukan tingkat kenegarawanan serta tingkat kecanggihan politik yang cukup tinggi untuk dapat menanganinya. 
Tantangan lainnya adalah jangan jadikan upaya pelestarian Pancasila sebagai upaya pelestarian "status quo”.

\section{Partisipasi Politik Masyarakat}

Dalam era globalisasi, negara harus dapat memberikan peranan sebesarbesarnya kepada rakyatnya. Pemberdayaan masyarakat, dalam arti memberikan peran dalam bentuk aktivitas dan partisipasi masyarakat untuk mencapai tujuan nasional (Tim lemhanas : 95).

Terdapat hubungan langsung dan timbal balik antara keharusan untuk menata kelembagaan politik dalam pengertian di atas dengan masalah partisipasi. Komitmen bangsa Indonesia terhadap Pancasila sebagai ideologi yang demokratis dan terbuka, mengangkat partisipasi politik sebagai masalah pokok. Fungsionalisasi serta peningkatan demokrasi dalam kelembagaan politik menuntut tumbuhnya partisipasinya politik. Sebaliknya juga, tuntuan partisipasi yang meningkat akan mengharuskan fungsionalisasi lebih lanjut dari lembaga-lembaga politik.

Peningkatan partisipasi akan menjadi kenyataan masa depan karena proses pembangunan nasional telah mewujudkan tuntutan serta harapan yang meningkat serta juga problema yang makin kompleks. Cara-cara penyelesaian persoalan yang semata-mata instruktif, serta penggunaan manusia dalam dunia politik untuk dijadikan obyek mobilisasi akan makin dirasakan bertentangan dengan nilai-nilai Pancasila.

Penyesuaian-penyesuaian dalam pengorganisasian intern kekuatan sosial plitik perlu ditempuh untuk menyediakan ruang partisipasi yang lebih besar, serta untuk mempertinggi drajad keterlibatan masyarakat dalam politik, termasuk dalam pengambilan keputusan sesuai dengan tuntutan demokratisasi. Pada gilirannya partisipasi kekuatan-kekuatan sosial politik dalam penentuan kebijakan nasional juga harus dapat tercermin secara fungsional serta semakin sesuai juga dengan asasasas demokrasi.

Pentingnya masalah partisipasi masyarakat mengharuskan untuk meninjau masalah politik tersebut dalam kaitan yang lebih luas. Dalam pengertian ini, maka 
setiap pengelompokan politik, termasuk didalamnya adalah organisasi-organisasi kemasyarakatan serta lembaga-lembaga swadaya masyarakat. Peningkatan peranan mereka mereka akan menumbuhkan kelompok-kelompok penekan terhadap kehidupan politik, yang tidak perlu ditafsirkan secara negatif, bahkan harus dilihat sebagai potensi partisipasi serta kontrol sosial. Banyak sekali prakarsa serta daya cipta masyarakat yang dapat diwujudkan secara konkrit melalui kegiatan-kegiatan yang terorganisasi dengan baik, yang pada gilirannya akan memberikan rasa percaya diri yang besar dalam masyarakat sehingga banyak manfaat yang dapat ditarik dari situasi semacam itu, seperti kemampuan masyarakat yang semakin tinggi untuk membangun dirinya yang berarti pula bahwa beban serta tanggung jawab nasional untuk menciptakan masyarakat adil dan makmur melalui pembangunan nasional tidak perlu semata-mata dipikul oleh besarnya peranan pemerintah belaka.

Terbukanya partisipasi merupakan sarana yang paling baik bagi kepemimpinan politik yang teruji. Tanpa dibukanya kesempatan partisipasi maka rekrutmen kepemimpinan politk akan selalu merupakan upaya yang penuh dengan resiko kegagalan, karena kepemimpinan yang dihasilkan semata-mata melalui proses mobilisasi, kurang dapat menjamin kualitas intrinsiknya.

\section{Kesimpulan}

1. Dari pembahasan di atas, dapat disimpulkan bahwa Kondisi Ketahanan Nasional Indonesia di bidang politik saat ini memprihatinkan banyak pihak. Oleh karena itu perlu diciptakan suatu sistem politik berlandaskan pancasila.

2. Untuk menciptakan sistem tersebut, harus ada upaya internalisasi nilai-nilai ideologi Pancasila, penataan kelembagaan dan partisipasi politik masyarakat.

3. Komunikasi politik serta keterbukaan akan merupakan kebutuhan dan dengan demikian suasana demokratis akan tumbuh dengan sendirinya. Hal ini amat bersesuaian dengan Pancasila sebagai ideologi yang demokratis dan terbuka dan sesuai dengan UUD 1945 yang menyatakan bahwa sesungguhnya kedaulatan berada di tangan rakyat. 
Bila bangsa Indonesia berhasil mengatasi ketiga masalah dalam kajian ini secara gemilang, maka akan tercipta kondisi politik yang dapat menjamin stabilitas keamanan dan mampu mengarahkan seluruh kekuatan dan potensi nasional untuk menciptakan kondisi Ketahanan_Nasional Indonesia yang tangguh dan ulet.

\section{Saran}

1. Perlu penyebarluasan nilai-niai ideologi Pancasila melalui berbagai jalur dalam bentuk yang lebih kreatif, inovatif dan tidak indoktrinatif.

2. Perlu diciptakan kondisi yang kondusif bagi pengoperasionalan Pancasila dalam semua aspek kehidupan dan bagi terciptanya lembaga-lembaga negara yang mampu berfungsi sesuai dengan yang dikehendaki oleh UUD 1945 dan bagi terciptanya suasana keterbukaan.

3. Perlu diciptakan suasana yang lebih memungkinkan timbulnya partisipasi politik masyarakat melalui pendidikan politik rakyat.

4. Perlu didorong tumbuhnya swadaya masayarakat agar dapat berperan dalam upaya menciptakan kemungkinan yang relatif lebih baik.

5. Perlu menghidupkan kembali mata kuliah Pancasila sebagai mata kuliah yang berdiri sendiri

\section{Daftar Pustaka}

Hamdan Mansoer. 2005. Pendidikan Kewarganegaraan di Perguruan Tinggi, sebagai dasar nilai dan pedoman berkarya bagi lulusan. Jakarta: Dirjen Dikti.

HAN Sobana. 2005. Pendidikan Kewarganegaraan (cetakan-4). Tanpa penerbit

Kaelan MS. 2004. Pendidikan Pancasila. Edisi Reformasi. Yogyakarta: Paradigma

Rahayu Minto, 2009, Pendidikan Kewarganegaraan, cetakan ke 2, Jakarta : Gramedia

Tim Lemhanas. 2000. Pendidikan Kewarganegaraan. Jakarta: Lemhanas

Winarno dan Sri Haryati. 2005. Pendidikan Pancasila UPT MKU UNS. Surakarta: Pustaka Cakra. 